\title{
Recovering core identity, hermeneutical and contextual preaching
}

\begin{tabular}{|c|c|}
\hline $\begin{array}{l}\text { Authors: } \\
\text { Craig Linden } \\
{\text { Malan } \mathrm{Nel}^{2}}^{2}\end{array}$ & \\
\hline $\begin{array}{l}\text { Affiliations: } \\
{ }^{1} \text { Baptist Unior } \\
\text { Africa, South }\end{array}$ & $\begin{array}{l}\text { of South } \\
\text { Africa }\end{array}$ \\
\hline $\begin{array}{l}{ }^{2} \text { Department } \\
\text { Theology, Uni } \\
\text { Pretoria, Sout }\end{array}$ & $\begin{array}{l}\text { of Practical } \\
\text { versity of } \\
\text { h Africa }\end{array}$ \\
\hline $\begin{array}{l}\text { Project Leade } \\
\text { Project Numb }\end{array}$ & $\begin{array}{l}\text { r: M. Nel } \\
\text { er: } 02331810\end{array}$ \\
\hline $\begin{array}{l}\text { Description: } \\
\text { This is a contr } \\
\text { a PhD in Pract } \\
\text { with the Univ } \\
\text { Pretoria, in th } \\
\text { congregation }\end{array}$ & $\begin{array}{l}\text { ibution toward } \\
\text { ical Theology } \\
\text { ersity of } \\
\text { e field of } \\
\text { I development. }\end{array}$ \\
\hline $\begin{array}{l}\text { Correspondin } \\
\text { Craig Linden, } \\
\text { craig.linden@ }\end{array}$ & $\begin{array}{l}\text { g author: } \\
\text { outlook.com }\end{array}$ \\
\hline $\begin{array}{l}\text { Dates: } \\
\text { Received: } 14 \\
\text { Accepted: } 24 \\
\text { Published: } 08\end{array}$ & $\begin{array}{l}\text { Dct. } 2015 \\
\text { Dec. } 2015 \\
\text { July } 2016\end{array}$ \\
\hline $\begin{array}{l}\text { How to cite th } \\
\text { Linden, C. \& } \\
\text { 'Recovering cc } \\
\text { hermeneutica } \\
\text { contextual pre } \\
\text { Teologiese Stu } \\
\text { Theological St } \\
\text { a3220. http:// } \\
\text { org/10.4102/l }\end{array}$ & $\begin{array}{l}\text { is article: } \\
\text { lel, M., 2016, } \\
\text { ore identity, } \\
\text { I and } \\
\text { eaching', HTS } \\
\text { dies/ } \\
\text { udies 72(3), } \\
\text { 'dx.doi. } \\
\text { tts.v72i3.3220 }\end{array}$ \\
\hline $\begin{array}{l}\text { Copyright: } \\
\text { (c) 2016. The } A \\
\text { Licensee: AOS } \\
\text { is licensed un } \\
\text { Creative Comr } \\
\text { Attribution Lic }\end{array}$ & $\begin{array}{l}\text { Iuthors. } \\
\text { IS. This work } \\
\text { ler the } \\
\text { nons } \\
\text { ense. }\end{array}$ \\
\hline Read online: & \\
\hline 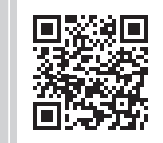 & $\begin{array}{l}\text { Scan this QR } \\
\text { code with your } \\
\text { smart phone or } \\
\text { mobile device } \\
\text { to read online. }\end{array}$ \\
\hline
\end{tabular}

The church has the privilege of participating with God in his saving mission in a broken and suffering world, also known as the missio Dei (Bosch 1991:8-11, 390-393). This is its core, missional identity. However, many local churches are facing an identity crisis at their very core. The reasons are numerous. This article seeks to define, in a theoretical and theological way, the core identity of the local church and in the light thereof to explore two areas: (1) how the local church and particularly its pastor view the core identity of the local church, and (2) whether the identity of the local church is affected through the ministry of preaching - preaching that takes into specific consideration the aspects of hermeneutics and context. The research indicates that while the church may have an understanding of its core identity - certainly when it answers the questions 'who are we?' and 'what are we called to be and/or do' - it lacks significantly in its missional identity. Contributing factors are mentioned and remedial action is proposed.

\section{Introduction}

From the earliest biblical records there are indications that God's people periodically suffered from an identity crisis. Biblical texts indicate that both Israel and the New Testament church were called to be a holy nation, a kingdom of priests, a chosen people, a treasured possession or a people belonging to God (cf. Ex. 19:6; Dt. 7:6; Dt. 10:15; 1 Pt. 2:9). This was the calling and sending of God's people in order that they might fulfil God's salvation plan for the world (see Branson 2007:102-104; Stott 2007:52-54). However, they often forgot their identity - who they were and what they had been called and sent to do. It was therefore necessary, as an example, for God 'to uproot and tear down, to destroy and overthrow, to build and to plant' (Jr. 1:10, NIV) in order that Israel might live out her identity as God's people. In the New Testament it was necessary, as an example, for the writers to rebuke the local church for being bewitched by a different gospel (Gl. 3:1), for drifting from God (Heb. 2:1), all of which negatively affected their identity. And while the Letter to the Ephesians and the First Epistle of Peter were not written with this primarily in mind, they do remind God's people of their unique identity and to live it out. In the sixteenth century, the age of the Reformation, we see how deformed the church had become or to what extent the church faced an identity crisis (see Heitink 2012:88ff.). Roxburgh (2008:76-77) suggests that it is no different today as churches struggle with the question of identity: identity at their very core. Whereas the issue of core identity in the local church is a recognisable problem and debate transpiring amongst practical theologians and in theological institutions, is it also a recognisable problem and debate amongst pastors and the local church? More specifically, is the question of core identity affected by the ministry of preaching?

\section{Contemporary evidence of a core-identity crisis in the local church}

Many churches are said to be sick because they have a false self-image: 'They have grasped neither who they are (their identity) nor what they are called to be (their vocation)' (Stott 1992:242). Easum $(2001: 88-89,2007: 6,76)$ purports that the vast majority of congregations are little more than hospices or hospitals, if not clubs. He suggests that they have a genetic code that is addicted to some form of cultural religion, which is far from biblical or spiritual. Dietterich (2004) states:

In the midst of a rapidly changing world, the church is being challenged to transform its basic identity and vocation... As the people of God we must rediscover whose we are, who we are, and what we are about in our life and witness. (pp. ix-x) 
Horton's works Christless Christianity (2008) and The gospeldriven life (2009) sum up the church as having been taken captive by the culture and ideals of the world - the culture and ideals of consumerism, pragmatism, self-sufficiency, individualism, positive thinking, personal prosperity and nationalism. The church's message and faith have become 'trivial, sentimental, affirming, and irrelevant' (Horton 2008:21). The Gospel is now a message of moralism, personal comfort, self-help, and self-improvement. The church's faith has become an individualistic religion that trivialises God and makes him a means to our selfish ends. Horton suggests that the church and our faith are well on their way to a Christless [sic] Christianity (see Horton 2008:15-100). He appeals to the church to return to its 'Good News' message, which has been replaced with a message of 'Good Advice' (Horton 2009:11). The goal of his book is to reorient the church's faith and practice toward the Gospel, the 'Good News'. The Gospel, he contends, is at heart 'Good News', not 'Good Advice', and it is this 'Good News' through which the church originates, flourishes, and fulfils its mission in the world (Horton 2009:11). Horton (2009) argues:

Only the radical news concerning Jesus Christ can distract us from all the trivial pursuits and transform us from the inside out. Only the gospel can cause such a radical re-evaluation of our core identity that we are willing, like Paul, to throw away what we thought was a great résumé in exchange for being found in Christ. (p. 22)

Long (2009:117) agrees with Horton's assessment of the modern church. He states that preachers in mainstream churches have become 'apostles of progress': moral progress, social improvement, the 'power of positive thinking', church growth, together with a psychotherapeutic gospel.

In support of the evidence that the local church faces a coreidentity crisis is the 'missional church conversation' (Guder 1998:7-12) that has exploded in theological circles. It is a conversation that not only explores but seeks to recover the missional identity of the local church. Nel (2015:205-346), in his most recent book Identity-driven churches, sets out to explain and explore how to develop local missional churches - churches with a missional identity. It is imperative that we do this, suggests Nel (2015:55), as congregations have ceased 'to be involved with God and his world'.

A reflection on this crisis leads to the following research question: While the issue of core identity is a debate or conversation transpiring in the theological realm - among practical theologians and in theological institutions - is the issue of core identity a debate or conversation in the pastoral realm - among pastors and the local church? Theologians have a definite view of the core identity of the local church (and they observe a dire need for the local church to recover its core identity), but do pastors and preachers of local churches share this view? What is their view of the core identity of the local church? What is their view of the churches reason-for-being? Are they a part of the missional church conversation? More specifically, does their preaching, or lack thereof, affect the question of core identity? These are important and necessary questions to ask if the church is to recover and reclaim its core identity. Before reporting on the 'view from the pew', the researcher will define in a theological and theoretical way the core identity of the local church.

\section{Defining the core identity of the local church}

Nel (2005:17) advocates that the core identity of the local church has to do with the church's understanding of its nature and its reason for existence (raison d'être) or, as Van Gelder (2007a:1-30) puts it, an understanding of its nature, its creation and continuing formation, and its purpose and ministry. To determine the church's core identity, two fundamental questions of paramount importance must be asked:(1) Who are we as the local church? (2) What are we called to be or what are we supposed to do? These two fundamental questions, and variations thereof, are supported by many theologians (see Barrett 2004:33-56; Dick 2007:17; Guder 2000:119; Heitink 1999:311; Nel 2005:25; Rouse \& Van Gelder 2008:31; Roxburgh 2008:76-77).

According to Branson (2007:102-104), the identity of the local church is to be found in the term 'church' (ekklessia). The word occurs 114 times in the New Testament and on the vast majority of occasions it refers to a local community of believers. The word ekklessía belongs in a word group that is concerned with call and voice. In classic Greek literature the word refers to a political assembly of citizens whose task was to decide about laws, policies and judicial rulings. It was an assembly who gathered (was called) for the purpose of having a specific influence on a larger social environment (a voice). Similarly, the church (ekklessia) in the New Testament is an assembly of believers who are called to have a voice in the world. The church is both called and sent by God to voice or participate in God's initiatives in Christ Jesus for the sake of the world (cf. Bullock 2008:106).

Arising out of the 'missional church conversation' (Guder 1998:7-12; Van Gelder 2008:2) that has taken place over several decades now, it has emerged that the identity and purpose of the church is missional in nature; that is, the church is 'missionary by its very nature, and this missionary nature is expressed as the church is sent by the Spirit into the world to participate in God's mission' (Van Gelder 2007b:28). Guder (2000:19) informs us that the theologian Karl Barth, in an address delivered at the Brandenburg Missionary Conference of 1932, was really the first to propose the idea that the Scriptures are a record of God's mission or God's sending to the world. Rather than seeing the church as having a mission or having an obligation to fulfil the Great Commission, it is really God who has a mission in the world and it is God who calls and sends the church to participate in this mission (see Guder 1998:3-4). Mission therefore began to be viewed as an essential theological characteristic of God (Guder 1998:4, 2000:19). In the ensuing years (1950-1970), at the International Missionary Council conferences, a Trinitarian understanding of mission 
was born. Three 'movements' were identified in the Scriptures (Bosch 1991:390): God the Father has sent the Son (Jn. 3:16); the Father and the Son have sent the Holy Spirit (Jn. 14:15); the Father, Son and Holy Spirit have sent the church into the world (Jn. 20:21). This understanding, in time, was formulated into what has become known as the missio Dei (mission of God) by Karl Hartenstein, and later still it was given a fuller expression by Johannes Blauw. Others, particularly the late Lesslie Newbigin, developed the idea. Central to Newbigin's understanding is that mission is the work of a triune God who calls and sends the church, through the agent of the Holy Spirit, into the world so as to participate fully in God's mission within the world (Newbigin 2006:83; Van Gelder 2007a:28-30, 2007b:2-3, 2008:2-6; see Guder 1998:81-83; Simpson 2007:75-77; also Van Gelder \& Zscheile 2011:26-46). $\mathrm{Nel}$ (2015:26) sums it up succinctly when he says: 'In the view of missional ecclesiology, it is God's mission that has a church, not the church that has a mission'. This is the real identity of the church (Nel 2015:25). Zscheile (2012) explains:

At the heart of the missional church conversation lies a challenge: to recover and deepen the church's Christian identity in a postChristendom world in light of the triune God's mission in all of creation. (p. 1)

\section{Research on 'core identity' and 'preaching' within the local church}

In order to ascertain what local pastors in the major cities of South Africa understand about the core identity of the local church, the researcher performed a qualitative survey in which 10 preachers in a mainline denomination were interviewed in an in-depth manner. Full consent was obtained from the interviewees. Answers to four questions were sought, namely, (1) What, in your understanding, is the (core) identity of the local church? (2) What, in your understanding, is the reason(s) for the church's existence? (3) Have you heard of and what do you understand by the term missional? and (4) Did their preaching in the local church, or lack thereof, affect the core identity of the local church?

\section{(1) What, in your understanding, is the (core) identity of the local church?}

What the researcher hoped to achieve in this question, was to solicit from each interviewee (without offering any promptings, ideas, suggestions) their personal view and understanding of the core identity of the local church. It was important not only to ascertain what their view and understanding of the identity of the local church was, but also how they would express their thoughts in their own words.

Without any promptings from the researcher, the interviewees identified the local church as the body of Christ. Various terms and phrases were used to articulate this:

'We are the sons and daughters of the most high God', 'children of God', 'the family of God', 'part of the family of God', 'those who are born-again', 'a union of spirit-filled believers under the Lordship of Christ', 'a regenerate, redeemed body of people brought together for fellowship and mission', 'a called people redeemed by Christ'.

One interviewee used the word ekklessia to describe the identity of the local church. The church is the 'called out ones ... separate from the world ... identified with Christ'. Another interviewee identified the church as a 'group of people gathered together in Christ's name to do what Christ has told us to do'. All the interviewees recognised that the church draws its identity from its relationship with God the Father. In a separate quantitative survey, conducted among 38 churches from this mainline denomination, most respondents concurred with the view of these preachers concerning the identity of the local church.

But then, without prompting from the interviewer, the interviewees also identified the local church in terms of what the church has been called to be and do. Once again, various terms and phrases were employed to describe or to qualify what the local church is called to be and do. We are to 'reflect Christ' and 'all we do must redound to his glory'. 'To this we were called', said one interviewee, 'to follow Christ ... to follow his example', namely, the church is to be an example of Christ or to model Christ so as to present Christ as the answer to the world. One interviewee defined the purpose of the church by using three words: glorifying, growing, and going. The mission statement of their local church is to 'glorify God, grow spiritually, and go into all the world and make disciples'. Another interviewee emphatically stated that the church does not exist solely for itself, but for the world; not for its own members, but for the non-members. His emphasis, as he put it, is on 'kingdom growth'. Still another interviewee said that the church must produce growth; it must motivate discipleship so that the church can bring people to God. 'The church must go beyond Sunday services', he insisted. 'It must be an organism of functionability [sic] every day - to bring more people to the Lord'. Another interviewee stated that the church exists 'to glorify God by spreading his fame and honour to the ends of the earth'. In the separate quantitative survey conducted among 38 churches from this mainline denomination, most, if not all the respondents, concurred with the view of these preachers concerning the identity of the local church in terms of what they are called to be and do.

\section{(2) What, in your understanding, is the reason(s) for the church's existence?}

Once again, what the researcher hoped to achieve in this question was to solicit from each interviewee (without offering any promptings, ideas, suggestions) their personal view and understanding of the reason(s) for the church's existence. Whereas this question was partly answered in the previous question, here the researcher strove to solicit a more definite, personal response from the interviewees regarding the reason(s) for the church's existence.

One interviewee remarked that the local church is called to be a royal priesthood under the high priest, Jesus Christ. 
The joy, privilege and responsibility of the local church is essentially that of service: speaking to God on behalf of the world and speaking to the world about God. In his own mind, intercession (speaking to God on behalf of the world) and evangelism (speaking to the world about God) were the core values or reason for the church's existence. Another interviewee chose biblical terms to define the reason for the church's existence. The local church exists to reach out, 'to be fishers of men, to go and make disciples', he declared, although it must first be equipped in order to do this effectively. Most of the interviewees referred to the concept of glorifying God as the church's reason for being. 'The fundamental reason is to glorify God', said one. 'The church exists for the glory of God by demonstrating his grace', said another. Still another: 'The church exists to declare the manifold wisdom of God'. Most of the interviewees also referred to the concept of being on mission for God as the reason for the church's existence. 'We exist to preach Christ to the world', said one, 'and what a privilege', he added. 'We exist to go ... to display the glory of God to the world', said another. And still another remarked: 'We exist for mission ... [W] e are co-labourers with Christ'. One interviewee chose biblical images to define the church's reason for being: '[T]o be light, salt ... those who go out to bring others in'. One interviewee summed up the reason for the church's existence in these words: 'Glorify [God] first, evangelism second'. Another summed it up succinctly in these words: 'Bring God to people; bring people to God'.

Only after the researcher had posed the above question and the interviewees had articulated their response did he pose three sub-questions. The sub-questions were: Could you comment on these statements namely, (1) The church exists to serve God; (2) The church exists to serve its members; and (3) The church exists to serve the world.

All the interviewees agreed, some more strongly than others, that the church exists to serve God, or that the church exists to glorify God. It became apparent that 'man's chief end in life is to glorify God ...' (Westminster Shorter Catechism). Similarly, all the interviewees agreed that the church exists to serve its members, or to build up its members, although this was not expressed as strongly as the previous point. In the same manner, all the interviewees agreed that the church exists to serve the world, or to use their terms: to 'evangelise the world; take the gospel to the world; spread the rule of Christ in the world'. Without exception, all the interviewees agreed with these three statements.

An interesting point of discussion ensued. Do these three statements carry equal weight or is one statement more important than the other? Scripture seems to indicate that all three elements are equally important and are not meant to be categorised either in order of priority or importance. Most of the interviewees agreed that these statements were co-equal in importance, or to use their terms, they were 'inter-related, interconnected and inseparable'. It was suggested that these three statements are like a three-legged chair: if one leg was missing, the chair would collapse. It was also suggested that the one statement either leads to or flows out of the other: glorifying God leads to growing and growing leads to going and going leads to glorifying God. One interviewee encapsulated the discussion in these words: 'God is most glorified when his people are enriched and people are reached'. While the interviewees agreed that all three statements were co-equal in importance, most were inclined to think that if there were to be an order of priority, then the first priority would be to glorify God.

\section{(3) Have you heard of and what do you understand by the term missional?}

In this question the researcher was eager to discover if the interviewees had heard the term missional, and if so, what was their understanding of it. The researcher bore in mind that the word missional means different things to different groups (Van Gelder 2008:preface), and the word is often misunderstood (Roxburgh \& Boren 2009:34). According to the 'missional church conversation' (Guder 1998:7-12; Van Gelder 2008:2), the word missional has something basic in mind. The missional church conversation presents an alternative way to think about the church. It revolves around the very nature or essence of what it means to be the church. It directs one to focus on God's mission as determinative for understanding the mission of the church (Van Gelder \& Zscheile 2011:9).

The key premise in the missional conversation is this: what the church is must deeply inform what the church does. Human agency is fully implicated in the doing, but such doing is always deeply informed and empowered by the agency of God working through the Spirit. Getting the sequence right is crucial for allowing God to become fully operative within the life and ministry of the church. That sequence is as follows: The church is. The church does what it is (Van Gelder \& Zscheile 2011:64; see Van Gelder 2000:30-32). The confusion surrounding the word missional then lies in the focus of the local church. Is the focus of the local church on God as the acting subject doing something in the world in which the church participates, or is the focus on the church as a human agency doing something on behalf of God in the world? For the interviewees then, did the term missional mean that the focus of the church is on God as the acting subject doing something in the world in which the church participates, or on man as the human agency doing something on behalf of God in the world?

All the interviewees had heard the term missional. While their understanding of the term was similar, the terminology used to express it differed widely. One interviewee defined the term missional as a mind-set that governs the church's attitude toward the world thereby driving it to take the gospel to the world. Some defined it as fulfilling God's mission on earth by keeping the Great Commission as expressed in Matthew 28:16-20. This should be a priority, they emphasised. They stressed the need to be more missionsminded, missions-involved, taking the church outside its building and even the need to be involved, vigorously, in 
church planting. Some were more personal in their interpretation of the term expressing it as 'intentional living' or 'intentional ministry for Christ' or even as 'living your life with gospel intention'. The emphasis here was that their life must represent Christ wherever they are. Every aspect of their life should present Christ to the world or that their life should reflect the glory of God in everything they do.

Without exception, the focus of the interviewees was on the church as the human agency doing something on behalf of God in the world rather than on God as the acting subject doing something in the world in which the church participates.

\section{(4) Did their preaching, or lack thereof, affect the core identity of the local church?}

The researcher explored not only the ministry of preaching in the local church, but the issue of what the researcher called 'hermeneutical preaching' and 'contextual preaching' within the local church. Hermeneutical preaching was defined by the researcher as preaching that takes into serious consideration all the principles of biblical interpretation. Contextual preaching was defined by the researcher as preaching that takes into serious consideration the context of the hearer or listener - both the modern and immediate environment in which the hearers find themselves. The presupposition was that if the ministry of preaching was being taken seriously in the local church, and, in particular, if hermeneutical and contextual preaching was being taken seriously in the local church, then the core identity of the local church would naturally emanate from that.

What were the findings? The ministry of preaching was indeed taking place within the local church. More than that, it was preaching of the highest order and most serious nature. Both hermeneutical and contextual preaching was also taking place within the local church. The principles of biblical interpretation and the context of the hearer-both their modern and immediate environment - were being given serious consideration. It was no surprise then that interviewees understood their core identity as the local church certainly in terms of 'who they were' and 'what they had been called to be and/or do'. Without exception, all the interviewees agreed with the statements expressed earlier: the church exists to serve God; the church exists to serve its members; the church exists to serve the world. It was surprising, however, that the hermeneutical and contextual preaching made no significant contribution to them understanding the missional identity of the local church. This was similarly the case among the respondents of a separate quantitative survey, conducted among 38 churches from this mainline denomination. This is understandable since the pastor or preacher of the local church largely conveys identity to the church.

\section{Summary of the findings}

All 10 interviewees (as well as the respondents of 38 churches) appear to have a clear, defined understanding of the core identity of the local church, certainly when it comes to answering the two fundamental questions of 'who are we?' and 'what are we called to be and/or do?' Concerning the term missional and its meaning, confusion and misunderstanding exist. While there may be misunderstanding about this word, it is evident is that these preachers are familiar with the word, it is being discussed, and, by all appearances, new ways of being the church are being explored. However, the overwhelming evidence suggests that many local churches have a crisis of missional identity. Even though hermeneutical and contextual preaching of a high order is taking place within the local church, it makes no significant contribution to the missional identity of the local church.

\section{Contributing factors to the crisis of identity}

- Internalisation: The qualitative survey of these 10 preachers (and the quantitative survey of congregation members of 38 churches) reveal that while these interviewees (and respondents) have an understanding of the core identity of the local church - who they are and what they are called to do - it is an intellectual understanding rather than an abiding vision, conviction and passionate outworking thereof. An intellectual understanding of the identity of the local church is essential and good, but more is required. It is a case of, as the biblical text puts it, '[i]n the same way, faith by itself, if it is not accompanied by action, is dead' (Ja 2:17, NIV).

- Individualism: In defining the core identity of the local church, a clear distinction must be made between corporate identity (the identity of the local church corporately) and individual identity (the identity of an individual believer within the local church). Many believers are enthusiastic about their personal and individual identity in Christ (Nel 2015:26), but what is needed is the recovery of the corporate sense of identity, the corporate self-image of the church (Nel 2005:367; cf. Dick 2007:17). A spirit of individualism in which believers view themselves as single, isolated and unattached entities prevails in the local church (see Heitink 2012:197, 205-208).

- Interpretation of a local missional church: Roxburgh and Boren (2009:31-34) are adamant that the word missional does not describe, for example, a church that emphasises cross-cultural missions, or a church that is using outreach programs to be externally focused, or a church that is effective at evangelism, or a church that has a welldefined mission statement with a vision and purpose for their existence (cf. Nel 2015:94-95). These are historical understandings of mission in the life of the church. As we have seen, the word missional has something more basic in mind. It directs one to focus on God's mission as determinative for understanding the mission of the church (Van Gelder \& Zscheile 2011:9). Alternatively, the term 'being missionary' is not what the church does, functionally, but more of what the church is in its very essence (Van Gelder 2008:42) The interviewees of the qualitative survey (and the respondents of the quantitative survey) have a more historic view of mission (the church 
is an agency on mission for God in this world) than a contemporary view of mission (the church is in mission with God in the world).

\section{Suggestions for remedial action}

It is with these thoughts in mind that the researcher makes a number of suggestions in the rediscovering and recovering of the core identity of the local church.

- A personal study of the core identity of the local church is needed. The advice of Van Gelder (2007a:1-30) is to constantly engage in the study of the church in order to explore its nature, understand its creation and continuing formation, and discover its purpose and ministry.

- There is a need to redefine the church as God's instrument for God's mission. Guder (1998:8) defines the church in this way: 'We have accepted the definition of the church as God's instrument for God's mission, convinced that this is scripturally warranted'. Nel (2015:66) defines it like this: '[T]he church is no casual reality; it originates in the will of the triune God, for the sake of the world'.

- Create a forum where preachers can actively engage in the missional church conversation.

- Preachers begin to read the Scriptures with a 'missional hermeneutic' (Guder 1998:11).

- Begin to preach on the essential nature and vocation of the church which is encapsulated in the term missional. Guder (1998:11) defines the term missional as such: 'With the term missional we emphasise the essential nature and vocation of the church as God's called and sent people'.

- The researcher has established that there is a strong link between 'hermeneutical and contextual preaching' and the core identity of the local church. Hermeneutical and contextual preaching needs to be pursued, but with a missional hermeneutic in mind or with an understanding of the missional church.

- A concerted effort in preaching on the missional nature and vocation of the church after the order of Thomas Long with enchantment and persuasion, in a way that excites the imagination and inflames the heart (Long 2009:5); or after the order of Martyn Lloyd-Jones - preaching that is both doctrinally sound and deep and yet at the same time crystal clear, logical and powerful (Piper 1990).

\section{Conclusion}

According to Rouse and Van Gelder (2008:33-34) there are three essential truths that not only stand out in the Bible but that also inform the local church of its holy identity and purpose. The first is that God is a creating God who has a plan for the world. God reveals this plan in the Bible, beginning with the creation of the world in Genesis and ending with the New Heaven and New Earth in Revelation. His plan is clear, namely that he created the world and that he has a plan for all life in this world - that life flourishes! The second truth is that God is a redeeming God who seeks to bring all of life into a reconciled relationship with himself. The intrusion of sin into this world has profoundly disrupted God's intent for all creation, and in order to redeem creation, a radical solution is required - nothing less than the incarnation, death and resurrection of his Son by which God deals with sin and reconciles creation to himself. The third truth is that God works out this reconciliation in this world through people. In all time God has used people to bear witness to his reconciling power and presence in this world. He has used many different people to serve his plan. He still does and he does it through the church today. This is the church's holy identity and purpose and this needs to be rediscovered and recovered in many local churches today.

\section{Acknowledgements Competing interests}

The authors declare that they have no financial or personal relationships which may have inappropriately influenced them in writing this article.

\section{Authors' contributions}

This is a contribution of C.L towards a PhD. In Practical Theology with the University of Pretoria, in the field of congregational development. M.N. was the project supervisor.

\section{References}

Barker, K. (ed.)., 1985, NIV Study Bible, Zondervan, Grand Rapids, MI.

Barrett, L.Y. (ed.), 2004, Treasures in clay jars: Patterns in missional faithfulness, William B. Eerdmans, Grand Rapids, MI.

Bosch, D.J., 1991, Transforming mission, Orbis Books, Maryknoll, NY.

Branson, M.L., 2007, 'Ecclesiology and leadership for the missional church', in C. van Gelder (ed.), The missional church in context, pp. 94-125, Wm. B. Eerdmans, Grand Rapids, MI.

Bullock, M.W., 2008, 'The challenge of developing missional denominational agencies and the implications for leadership', in C. van Gelder (ed.), The missional church and denominations, pp. 104-130, Wm. B. Eerdmans, Grand Rapids, MI.

Dick, D.R., 2007, Vital signs: A pathway to congregational wholeness, Discipleship Resources, Nashville, TN.

Dietterich, I.T., 2004, 'Foreword', in M.L. Branson (ed.), Memories, hopes, and conversations: Appreciative inquiry and congregational change, $\mathrm{pp}$. ix- $\mathrm{x}$, Alban Institute, Herndon, VA.

Easum, W.M., 2001, Unfreezing moves: Following Jesus into the mission field, Abingdon Press, Nashville, TN.

Easum, W.M., 2007, A second resurrection: Leading your congregation to new life, Abingdon, Nashville, TN.

Guder, D.L. (ed.), 1998, Missional church: A vision for the sending of the church in North America, Wm. B. Eerdmans, Grand Rapids, MI.

Guder, D.L., 2000, The continuing conversion of the church, Wm. B. Eerdmans, Grand Rapids, MI.

Heitink, G., 1999, Practical theology, Wm. B. Eerdmans, Grand Rapids, MI.

Heitink, G., 2012, Golfslag van de tijd, Kok, Kampen.

Horton, M., 2008, Christless Christianity, Baker, Grand Rapids, MI.

Horton, M., 2009, The gospel-driven life, Baker, Grand Rapids, MI.

Long, T.G., 2009, Preaching from memory to hope, Westminster John Knox Press, Louisville, KY.

Nel, M., 2005, Who are we?, Kitskopie, Pretoria, transl. from the original Gemeentebou, 1994, Orion, Halfway House, Johannesburg.

Nel, M., 2015, Identity-driven churches, Biblecor, Wellington.

Newbigin, L., 2006, Trinitarian doctrine for today's mission, Wipf \& Stock, Eugene, OR. Piper, J., 1990, The supremacy of God in preaching, Baker, Grand Rapids, MI.

Rouse, R. \& Van Gelder, C., 2008, A field guide for the missional congregation, Augsburg Fortress Press, Minneapolis, MN.

Roxburgh, A.J., 2008, 'Denominations from a missional perspective', in C. van Gelder (ed.), The missional church and denominations, pp. 75-103, Wm. B. Eerdmans, Grand Rapids, MI. 
Roxburgh, A.J. \& Boren, M.S., 2009, Introducing the missional church, Baker, Grand Rapids, MI.

Simpson, G.M., 2007, 'A Reformation is a terrible thing to waste: A promising theology for an emerging missional church', in C. van Gelder (ed.), The missional church in context, pp. 65-93, Wm. B. Eerdmans, Grand Rapids, MI.

Stott, J.R.W., 1992, The contemporary Christian, InterVarsity Press, Leicester

Stott, J.R.W., 2007, The living church, InterVarsity Press, Downers Grove, IL.

Van Gelder, C., 2000, The essence of the church: A community created by the Spirit, Baker, Grand Rapids, MI.
Van Gelder, C., 2007a, The ministry of the missional church: A community led by the Spirit, Baker, Grand Rapids, MI.

Van Gelder, C., 2007b, The missional church in context, Wm. B. Eerdmans, Grand Rapids, MI.

Van Gelder, C., 2008, The missional church and denominations, Wm. B. Eerdmans, Grand Rapids, MI.

Van Gelder, C. \& Zscheile, D.J., 2011, The missional church in perspective, Baker, Grand Rapids, MI.

Zscheile, D.J., 2012, Cultivating sent communities: Missional spiritual formation, Wm. B. Eerdmans, Grand Rapids, MI. 